\title{
Ocorrência sorológica e molecular de Anaplasma marginale em bovinos de corte amostrados no Pantanal sul-matogrossense
}

Inalda Angélica de Souza Ramos;, Heitor Miraglia Herrera, Luiz Ricardo Gonçalves, Otavio Luiz Fidelis Junior, Simone de Jesus Fernandes, Diego Carlos de Souza Zanatto, João Bosco Vilela Campos, João Vitor Almeida Alves, Rosangela Zacarias Machado, Marcos Rogério André

Faculdade de Ciências Agrárias e Veterinárias, Universidade Estadual Paulista (UNESP), Jaboticabal, SP, Brasil

*Autor correspondente

e-mail: inaldasouzaramos@outlook.com

\section{Resumo}

Anaplasma marginale (Rickettsiales: Anaplasmataceae) apresenta distribuição mundial e causa anemia severa com alta morbidade e mortalidade em bovinos. 0 presente trabalho teve como objetivo avaliar a ocorrência sorológica e molecular de A. marginale em amostras de sangue de vacas da raça Nelore (Bos taurus indicus) no Pantanal sul-matogrossense, pelo ensaio imunoenzimático indireto (iELISA) e qPCR (Real-Time $P C R$ ) baseada no gene msp1 $\beta$, respectivamente. Para tal, foram colhidas amostras de sangue total e soro de 126 vacas nascidas e criadas em três propriedades do Pantanal sul-matogrossense, município de Corumbá, sub-região da Nhecolândia, as quais foram selecionadas por conveniência. As amostras de sangue colhidas com anticoagulante EDTA foram submetidas à extração de DNA, utilizando a técnica de fenol-clorofórmio. Posteriormente, a concentração do DNA e relações 260/280 e 260/230 foram mensuradas em aparelho espectrofotômetro. Para verificar a presença de inibidores, foi realizado um ensaio de PCR convencional para o gene endógeno GAPDH. As amostras positivas na $\mathrm{cPCR}$ supracitada foram submetidas à qPCR para A. marginale baseada no gene msp1 $\beta$. Das 126 vacas avaliadas, 65,07\% (82/126) e 43,66\% (55/126) mostraram-se positivas nos ensaios de iELISA e qPCR para A. marginale, respectivamente.No total, as vacas mostraram-se 40,38\% (21/52) positivas na qPCR e soronegativas no iELISA; 59,61\% (31/52) negativas na qPCR e soropositivas no iELISA. Os níveis riquetsêmicos estimados pela qPCR nos animais positivos variaram de $1,05 \times 10^{3}$ a 1,44 x $10^{7}$ cópias de um fragmento do gene msp $1 \beta$ por microlitro, sugerindo casos de infecção aguda e crônica nas propriedades amostradas. 0 teste de concordância kappa revelou um índice de 0,14 , indicando uma concordância leve entre os dois testes utilizados. 